\title{
STRATEGI DAN MANAJEMEN DAKWAH LEMBAGA DAKWAH ISLAM INDONESIA (LDII) KECAMATAN TUGU KOTA SEMARANG
}

\author{
Novi Maria Ulfah \\ Universitas Islam Negeri (UIN) Walisongo Semarang \\ Email: unonovi@gmail.com
}

\begin{abstract}
Abtract
The purpose of this study was to determine the strategy and the management of the Indonesia Institute of Islamic Dawah (LDII) in District Tugu Semarang. In this study, the writer used an interview method toward the LDII Chairman of the district. Indeed, she also used the literature method by using the books, the documents, the articles and the reports to complete this study. The findings showed that as an organization, LDII uses good strategy and management in conducting Islamic da'wah. The strategies include some aspects of religion, sport, and cadre to the LDII congregations. Its activities are usually conducted daily, weekly, and annually. This study, then, gives some recommendation to conduct a sustainable research on the strategy and management of LDII in District Tugu Semarang. In addition, it is proven that LDII can socialize with other Muslims in carrying out religious practices, so people do not need to consider this group as an Islamic Jamaah because in some cases, most people still think about it.
\end{abstract}

$* * *$

Tujuan penelitian ini adalah untuk mengetahui strategi serta manajemen yang digunakan Lembaga Dakwah Islam Indonesia di Kecamatan Tugu Kota Semarang. Metode yang dipergunakan dalam penelitian ini menggunakan metode wawancara dengan Ketua LDII Kecamatan Tugu. Selain menggunakan metode wawancara, juga menggunakan metode kepustakaan. Penulis menggunakan buku, dokumen, artikel serta laporan untuk melengkapi penelitian ini. Temuan dari penelitian ini antara lain: 1) Sebagai sebuah organisasi, LDII menggunakan strategi dan manajemen yang baik dalam melakukan dakwah Islam. 2) Strategi dakwah yang digunakan oleh LDII mencakup strategi di bidang keagamaan, di bidang olahraga, serta pengkaderan bagi jamaahnya. Kegiatan di dalam LDII bersifat harian, mingguan sampai tahunan. Rekomendasi dalam penelitian ini antara lain:1) Adanya penelitian yang berkelanjutan terhadap strategi dan manajemen LDII di Kecamatan Tugu. 2) Dalam menjalankan ritual keagamaan, LDII bisa membaur dengan umat Islam lainnya, sehingga masyarakat tidak menganggap LDII sebagai Islam Jamaah. Sebagian masyarakat masih menganggap bahwa LDII adalah Islam Jamaah.

Keywords: Strategy, Management, the Indonesia Institute of Islamic Dawah (LDII) 


\section{A. Pendahuluan}

Islam adalah agama dakwah ${ }^{1}$ artinya agama yang selalu mendorong pemeluknya untuk senantiasa aktif melakukan kegiatan dakwah, menyebarkan prinsip-prinsip Islam. Maju mundurnya umat Islam sangat bergantung dan berkaitan erat dengan kegiatan dakwah yang dilakukannya, ${ }^{2}$ karena itu $\mathrm{Al}$ Quran dalam menyebut kegiatan dakwah dengan istilah Ahsanu Qaula ${ }^{3}$. Dengan kata lain bisa disimpulkan bahwa dakwah menempati posisi yang tinggi dan mulia dalam kemajuan agama Islam. Terlebih lagi di era globalisasi saat ini, dimanaberbagai arus informasi masuk begitu cepat dan instan tidak terbendung, kegiatan dakwah sangat dibutuhkan oleh Umat Islam. Dakwah Islam memberikan filter untuk memilah dan dan menyaring informasi tersebut sehingga tidak bertentangan dengan nilai-nilai Islam. ${ }^{4}$

Berbicara aktifitas dakwah di Indonesia belum menunjukkan hubungan yang sinergis dan fungsional antara kajian yang bersifat akademis dengan realitas dakwah yang ada di masyarakat.Kesenjangan antara dunia akademis dan realitas sosial dakwah Islam masih terjadi. Masing-masing berjalan sendiri. Kajian akademik masih asyik di menara gadingnya, sementara praktik dakwah di masyarakat masih berkutat pada model-model dakwah konvensional(ceramah) yang telah berjalan bertahun-tahun dan belum menunjukkan adanya perubahan yang berarti.

Di kalangan akademisi dan para pakar di bidang dakwah, mereka mengkaji dakwah kebanyakan bertitik tolak dari sumber-sumber normatif, yaitu Al Qurandan Hadits. Mereka belum membangun kajian yang bertitik tolak dari realitas sosial yang ada di masyarakat. Kejadian-kejadian yang menimpa umat Islam seperti kemiskinan, kerusuhan, ketidakadilan, disintegrasi dan sebagainya belum menjadi perhatian dari para akademisi dan pemikir dakwah. ${ }^{5}$

Lembaga Dakwah Islam Indonesia (LDII) sebagai salah satu organisasi dakwah menyadari betul akan hal itu, maka organisasi ini melakukan dakwah secara ekternal dan secara internal. Secara ekternal yaitu dengan cara

\footnotetext{
${ }^{1}$ M, Masyhur Amin, Dakwah Islam Dan Pesan Moral, (Jakarta: al Amin Press, 1997), hlm 8.

${ }^{2}$ Didin Hafiduddin, M.Sc, Dakwah Aktual, (Jakarta: Gema Insani Press. Cet 3, 1998), hlm

76.

3 Surat Fushilat: 33

${ }^{4}$ Drs.H. Munzier Suparta,M.A dan H. Harjani Hefni, Lc, M.A, Metode Dakwah, (Jakarta: Kencana Prenada Media Group. Cet 3, 2009), hlm 5

5 Tulisan-tulisan yang berbicara tentang dakwah umumnya masih menurunkan teori yang bersumber dari al Quran dan al Hadits seperti buku fiqh dakwah karya Sayyid Qutb, M.Natsir, Jumah Amin Abdul Aziz dan beberapa buku lain.
} 
meningkatkan jumlah jamaahnya (kuantitas). Sedangkan dari kualitas, mereka meningkatkan kajian keagamaan kepada para jamaahnya.Oleh karena itu, dalam tulisan ini akan menggambarkan bagaimana strategi serta manajemen dakwah yang digunakan oleh LDII di Kecamatan Tugu.

\section{B. Pembahasan}

\section{Strategi dan Manajemen Dakwah}

Strategi dakwah adalah metode siasat, taktik atau manuver yang dipergunakan dalam aktifitas dakwah. ${ }^{6}$ Awal penggunaan kata strategi dipergunakan dalam dunia militer. Lebih lanjut, Asmuni menambahkan, strategi dakwah yang dipergunakan dalam usaha dakwah harus memperhatikan beberapa hal, antara lain: 1) Azas filosofi, yaitu azas yang membicarakan tentang hal-hal yang berkaitan dengan tujuan yang hendak dicapai dalam proses dakwah. 2) Azas psikologi yaitu azas yang terkait dengan kejiwaan manusia. Seorang da'i adalah manusia, begitu juga sasaran serta objek dakwah yang memiliki karakter kejiwaan yang unik.3) Azas sosiologi, yaitu azas yang membahas masalah yang terkait dengan situasi dan kondisi sasaran dakwah. Misalnya, politik masyarakat setempat, mayoritas agama di daerah setempat, filosofi sasaran dakwah, sosiokultur dan lain sebagainya yang sepenuhnya diarahkan pada persaudaraan yang kokoh, sehingga tidak ada sekat di antara elemen dakwah, baik kepada obyek (mad'u) maupun kepada sesama subyek (pelaku dakwah).

Dalam memahami keberagamaan masyarakat, antara konsepsi psikologis, sosiologi dan religiusitas hendaknya tidak dipisahkan secara ketat, sebab jika terjadi percampuradukan maka akan menghasilkan kesimpulan yang fatal.7 Selain ketiga hal tersebut diatas patut juga dipertimbangkan, pertama azas kemampuan dan keahlian (achievement and professional), yaitu azas yang menekankan pada kemampuan dan profesionalisme subyek dakwah dalam menjalankan misinya. Latar belakang subyek dakwah akan dijadikan ukuran kepercayaan mad'u. Kedua, azas efektifitas dan efisiensi yaitu azas yang menekankan usaha melaksanakan kegiatan dengan semaksimal mungkin sesuai dengan planning yang telah di tetapkan sebelumnya.Sehingga dalam pelaksanaan dakwah Islam sangat dibutuhkan mengelolaan melalui managemen yang tersusun dan terencana.

${ }^{6}$ Asmuni Sukir, Dasar-Dasar Strategi Dakwah Islam (Surabaya: Al Ikhlas, 1983), hlm 32.

${ }^{7}$ Ahmad Anas, Paradigma Dakwah Kontemporer, Aplikasi Dan Praktisi Dakwah Sebagai Solusi Problematika Kekinian (Cet 1; Semarang: Pustaka Rizki Putra, 2006),hlm 184. 
Secara sederhana, manajemen adalah upaya mengatur dan mengarahkan berbagai sumber daya, mencakup manusia (man), uang (money), dan barang (material), mesin (machine), metode (method) dan pasar (market). ${ }^{8}$ Namun, secara khusus definisi manajemen, seperti yang dikemukakan oleh G.R Terry dalam bukunya Principles of Management, adalah; "Management is a district process of planning, organizing, actuating and controlling, perform to determine and accomplish stated objectives by the use of human beings and other resources." 9

Definisi di atas memberikan gambaran bahwa manajemen mengandung arti proses kegiatan. Proses tersebut di mulai dari perencanaan, pengorganisasian, pelaksanaan, pengawasan dengan menggunakan sumber daya manusia dan sumber daya lainnya. ${ }^{10}$ Seluruh proses tersebut ditujukan untuk mencapai tujuan yang telah ditetapkan.

Sedangkan A Rosyad Shaleh ${ }^{11}$ mengartikan manajemen dakwah sebagai proses perencanaan tugas, mengelompokkan tugas, menghimpun dan menempatkan tenaga-tenaga pelaksana dalam kelompok-kelompok tugas dan kemudian menggerakkan kearah pencapaian tujuan dakwah. Inilah yang merupakan inti dari manajemen dakwah yaitu sebuah pengaturan secara sistematis dan koordinatif dalam kegiatan atau aktifitas dakwah yang dimulai dari sebelum pelaksaan sampai akhir dari kegiatan dakwah.

Strategi dalam organisasi dakwah difokuskan pada unsur-unsur sebagai berikut: pertama inovasi para pelaku dakwah yang akan mencerminkan usaha organisasi untuk mengejar inovasi menghadapi mad'u.Kedua, minimalisasi biaya yang mencerminkan usaha organisasi untuk melakukan pengendalian biaya secara ketat dalam aktifitas dakwah. ${ }^{12}$

Strategi dakwah yang dilakukan oleh LDII lebih meningkatkan pemahaman keagamaan terhadap para angotanya. Meskipun jumlah jamaahnya dapat meningkat tetapi yang menjadi fokus dakwahnya kepada peningkatan terhadap paham keagamaan.

${ }^{8}$ H. Zaini Muchtarom, Dasar-Dasar Manajemen Dakwah. (Yogyakarta: Al Amin Press, 1996), hlm 35 .

${ }_{9}$ G.R Terry, Principles Of Management,Georgetown,(Richard D.Irwing Inc, sixth edition. 1972), hlm 4. Terjemahan bebas: manajemen adalah proses yang khas terdiri dari perencanaan, pengorganisasian, pelaksanaan dan pengawasan yang dilakukan untuk menentukan dan mencapai tujuan yang telah ditetapkan dengan menggunakan tenaga dan sumber daya lainnya.

10 M. Munir dan Wahyu Ilaihi. Manajemen Dakwah, (Jakarta: Kencana Prenada Media Group. Cet 3, 2006), hlm VIII

${ }^{11}$ A. Rosyad Shaleh, Manajemen Dakwah Islam. (Jakarta: Bulan Bintang. 1993), hlm 123

12M. Munir dan Wahyu Ilaihi.Opcit, hlm 136. 
Metode pengumpulan data dalam penelitian ini menggunakan: 1) Wawancara. Wawancara adalah percakapan dengan maksud tertentu. ${ }^{13} \mathrm{Lebih}$ lanjut Lexy menjelaskan percakapan itu dilakukan oleh dua pihak, yaitu pewawancara yang mengajukan pertanyaan dan yang diwawancarai yang memberikan jawaban atas pertanyaan. Dalam hal ini penulis melakukan wawancara secara intensif terhadap ketua LDII Kecamatan Tugu yaitu Bapak Sarmin.2) Kajian kepustakaan. Kajian kepustakaan (library research) adalah penelitian yang datanya diambil terutama atau seluruhnya dari kepustakaan (buku, dokumen, artikel, laporan, koran dan lain sebagainya). ${ }^{14}$ Penulis menggunakan buku, dokumen, artikel serta laporan sebagai penunjang untuk melengkapi penelitian ini.

Jenis penelitian ini termasuk ke dalam penelitian kualitatif. Sebagaimana ditulis oleh Bogdan dan Taylor dalam bukunya Lexy, penelitian kualitatif dapat didefinisikan sebagai prosedur penelitian yang menghasilkan data deskriptif berupa kata-kata tertulis atau lisan dari orang-orang dan perilaku yang dapat diamati. ${ }^{15}$ Dengan kata lain, penelitian kualitatif diartikan sebagai penelitian yang tidak mengadakan hitungan. Walaupun demikian penelitian kualitatif, bisa menyediakan informasi penting yang kemudian bisa dijelajahi lebih lanjut melalui riset kuantitatif. ${ }^{16}$

\section{Profil Lembaga Dakwah Islam Indonesia (LDII)}

Organisasi LDII pertama kali berdiri pada tanggal 3 Januari 1972 dengan nama Yayasan Lembaga Karyawan Islam (YAKARI). Pada Musyawarah Besar (Mubes) tahun 1981 namanya berganti menjadi lembaga karyawan Indonesia (LEMKARI), dan pada Mubes tahun 1990 sesuai dengan arahan Jenderal Rudini sebagai Menteri Dalam Negeri (Mendagri) waktu itu,nama LEMKARI yang sama dengan akronim lembaga Karate-Do Indonesia diubah menjadi Lembaga Dakwah Islam Indonesia. Namun dari nama asal tersebut ada yang menyebut sejarah LDII asalnya Darul Hadits kemudian berubah menjadi LEMKARI dan berubah lagi menjadi LDII hingga saat ini. ${ }^{17}$

${ }^{13}$ Lexy J Moeloeng, Metodologi Penelitian Kualitatif, (Bandung: CV Remaja karya, 1989), hlm 148.

14Wirawan Prasetya. Logika Dan Prosedur Penelitian, ( Jakarta: Sekolah Tinggi Ilmu Administrasi, cet kedua, 2000), hlm 65.

15Lexy, opcit. Hlm 2

16Drs Husein Umar, Metode Penelitian Untuk Skripsi Dan Tesis Bisnis, (Jakarta:PT Rajagrafindo Persada, 2000), hlm36.

17http//www.ldii.or.id, diakses pada tanggal 27 Desember 2013 
Lembaga Dakwah Islam Indonesia merupakan organisasi kemasyarakatan yang resmi dan legal yang mengikuti ketentuan UU no.8 tahun 1985 tentang Organisasi Kemasyarakatan, serta pelaksanaannya meliputi peraturan pemerintah (PP) no 18 tahun 1986.18 LDII memiliki Anggaran Dasar (AD) dan Anggaran Rumah Tangga (ART), program kerja dan pengurus mulai dari tingkat pusat sampai dengan tingkat desa (kelurahan). Keberadaan LDII sudah tercatat di Badan Kesatuan Bangsa dan Perlindungan Masyarakat (Bakesbang dan Linmas) Departemen Dalam Negeri. LDII bergerak dalam bidang keagamaan dan sosial ( Islam) yang berkantor pusat di jl Arteri Tentara Pelajar no 28 Patal, Senayan, Jakarta Selatan, DKI Jakarta. Organisasi ini mempunyai keanggotaan secara total sebanyak 15 juta (tahun 2005) dengan ketua umumnya Prof. Dr. Ir . K.H. Abdullah Syam, M.Sc.

Sesuai dengan Anggaran Dasar pasal 6, LDII bertujuan untuk meningkatkan kualitas peradaban, hidup, harkat dan martabat dalam kehidupan bermasyarakat, berbangsa dan bernegara serta turut dalam pembangunan manusia Indonesia seutuhnya, yang dilandasi oleh keimanan dan ketaqwaan kepada Tuhan Yang Maha Esa guna terwujudnya masyarakat madani yang demokratis dan berkeadilan sosial berdasarkan Pancasila yang diridhoi oleh Allah SWT.

Sebagai organisasi keagamaan LDII senantiasa berupaya untuk meningkatkan jumlah anggota, sekaligus sebagai bentuk pengkaderan dan regenerasi organisasi. LDII tidak memberikan batasan dalam rekruitmen anggota baru. Setiap saat anggota masyarakat dapat secara terbuka bergabung dengan ketentuan yang telah di atur oleh Anggaran Dasar Organisasi. Sarat untuk menjadi anggota LDII berdasarkan Anggaran Dasar Pasal 14. Yaitu yang terpenting anggota LDII adalah warga Negara Indonesia. Pertama,Percaya dan takwa kepada Tuhan Yang Maha Esa.Kedua, Setia kepada Pancasila dan UUD 1945. Ketiga,Menyatakan diri dengan sukarela menjadi anggota LDII. Keempat,menerima, menyetujui, dan sanggup taat terhadap AD dan ART LDII, serta seluruh keputusan musyawah dan rapat-rapat, serta peraturan organisasi, dankelimabersedia mengikuti segala kegiatan sesuai dengan program kerja organisasi.

LDII Kecamatan Tugubaru berdiri secara resmi pada tahun 2005, karena sebelumnya masih menginduk ke pengurus cabang yang lain. Pada waktu itu LDII Kecamatan Tugudi ketuai oleh bapak. H. Muh Zaeni, S.E .Sampai sekarang pengurus cabang LDII KecamatanTugu masih mempunyai satu cabang pengurus anak cabang yaitu Kelurahan Tugurejo. Kemungkinan besar

18.Subkhan Ridho, Dinamika Keberagamaan Lembaga Dakwah Islam Indonesia Kalipancur, Tidak Dipublikasikan ( Semarang: Balai Penelitian Dan Pengembangan Agama Islam, 2010),hlm 7. 
lima bulan kedepan akan dibuka pengurus anak cabang baru di kelurahan Karanganyar dan Jrakah.(Wawancara Bapak Sarmin, selaku ketua LDII Kecamatan Tugurejo, pada tanggal 25 Oktober 2013 ).

Sedangkan struktur kepengurusan Lembaga Dakwah Islam Indonesia 2010-2015 Kecamatan Tugu:

Ketua

Wakil Ketua

Sekretaris

Wakil Sekretaris

Bendahara

Seksi-seksi:

Seksi Agama dan Dakwah

Seksi Pemuda dan Olahraga

Seksi Komunikasi, Informasi dan Media

Seksi Pemberdayaan Wanita dan

Kesejahteraan Keluarga
:Sarmin

: Maarif, ST

: Dulrokhim

: Subantoro

: Rohmat

: H. Yunus

: Suparmin

: Widodo

: Siti Zulaekhah

Idealnya dalam satu pengurus cabang ditingkat kecamatan mempunyai minimal tiga anak cabang yang terdapat di setiap kelurahan. Bahkan dalam satu pengurus anak cabang bisa mencapai 3-10 pengurus anak cabang. Dibandingkan dengan pengurus cabang di kecamatan yang lain,pengurus cabang LDII di Kecamatan Tuguyang paling sedikit anggota dan fasilitasnya.

Dalam menjalankan aktifitas keberagamaannya, paraanggota atau jamaah tidak harusterpaku dengan tempat tinggalnya. Tetapi para anggota LDII di Kecamatan Tugu dapat mengikuti kajian di masjid LDII di tempat lain seperti di Puncak Sari Ngalian, Sapta Marga Krapyak, Jrakah atau pun Karanganyar.

Sebelumnya LDII mendapatkan label negatif, sebagai organisasi yang bersebrangan dengan pokok-pokok ajaran Islam. Akan tetapi, LDII sekarang telah menganut paradigma baru. LDII bukanlan penerus/ kelanjutan dari Islam Jamaah serta tidak mengajarkan ajaran Islam Jamaah. LDII tidak menggunakan ataupun sistem keamiran. LDII tidak menganggap umat Islam di luar kelompok mereka sebagai kafir atau najis. LDII bersedia bersama dengan ormas-ormas Islam lainnya mengikuti landasan berfikir keagamaan sebagaimana yang ditetapkan oleh MUI.

Paradigma baru LDII belum secara 100 \% diaplikasikan secara keseluruhan karena LDII masih menggunakan produk lama seperti buku khotbah. Buku khotbah yang digunakan masih menggunakan buku khotbah lama yang isinya masih menggunakan kata-kata jamaah. Selain itu LDII masih 
menjaga keeklusifannya dengan cara tidak mau membaur ketika melakukan ibadah shalat.

\section{Lingkungan Strategis}

Keberadaan sebuah organisasi tentu tidak bisa lepas dari lingkungan sosial dan kemasyarakatan yang melingkupinya. Lingkungan strategis yang mempengaruhi arah perubahan visi dan missi LDII secara umum di bedakan dalam dua faktor utama yaitu,faktor eksternal dan internal.Faktor eksternal memberi gambaran mengenai kondisi masyarakat Kecamatan Tugu dimana organisasi LDII berada. Faktor ini mencakup kondisi politik, ekonomi, sosial budaya serta ilmu pengetahuan dan teknologi.

\section{a. Faktor Politik}

Dalam bidang politik praktis, anggota Lembaga Dakwah Islam Indonesia tidak berafiliasi ataupun bergabung kepada salah satu partai nasional. Melainkan para anggota LDII di beri kebebasan untuk memilih salah satu partai sesuai dengan pilihan hati nuraninya sendiri. Tidak ada himbauan atau pun instruksi dari pucuk pimpinan untuk mengikuti salah satu partai nasional.

LDII merupakan organisasi kemasyarakatan yang independen yang tidak mengikatkan diri ke partai politik manapun. Adapun pada saat pemilu, tanpa mengurangi nilai demokrasi, aspirasi politik warga LDII disalurkan sesuai dengan Rapat Kerja Nasional (Rakernas) menjelang pemilu. LDII tetap menjaga netralitas dengan pihak manapun. LDII juga tidak golput, menerima dan menghormati seluruh hasil keputusan KPU/KPUD. Memberi selamat kepada yang menang dan bagi yang kalah melakukan pendekatan dengan mengedepankan nilai-nilai yang luhur. Pada Munas tahun 2005, Munas VI LDII merekomendasikan agar dukungan terhadap para calon diserahkan pada "keputusan" masing-masing pribadi ataupun simpatisan, mendukung sepenuhnya kepada pengurus atau warga LDII yang menjadi calon dalam pilkada.

\section{b. Faktor Ekonomi}

Masyarakat di Kecamatan Tugubanyak yang bekerja sebagai buruh pabrik. Hal ini dapat diketahui dengan adanya banyak pabrik yang terletak di sepanjang jalan tapak di Kecamatan Tugu. Pabrik-pabrik tersebut antara lain, Pabrik Indofood yang memproduksi sirup, saus, kecap serta mie. Pabrik Sami yang memproduksi kabel instalasi kelistrikan mobil.Pabrik Kharisma yang memproduksi mebel serta pertukangan. Pabrik Indie/Brilliant yang memproduksi gelas, piring, teko dll. Pabrik Marie Albert serta Country yang 
bergerak dalam bidang mebel/ kayu. Pabrik Samator Gas yang bergerak dalam distribusi tabung gas.

Dengan banyaknya pabrik-pabrik di Kecamatan Tugumenjadikan warga Tugu mayoritas mempunyai mata pencaharian sebagai pekerja pabrik. Selain menjadi buruh pabrik, para orang tua yang sudah tidak bekerja mempunyai usaha kos-kosan bagi para pekerja pabrik yang berasal dari berbagai daerah. Selain itu, mata pencaharian yang lain yang banyak dilakukan adalah menjadi sopir, serta menjadi pedagang.

\section{c. Faktor Sosial dan Budaya}

Sebagian masyarakat Tugu asli masih percaya adanya takhayul dan khurafat, hal ini juga dipengaruhi oleh faktor pemahaman keagamaan yang rendah. Karena berada dalam lingkungan pabrik, faktor pendidikan, kesehatan, serta agama kurang diperhatikan. Mereka hanya mampu menyekolahkan anak-anaknya sampai jenjang Sekolah Menengah Kejuruan (SMK). Anak-anak dimasukkan ke dalam SMK dengan harapan setelah lulus sekolah anak anak tersebut tidak perlu kuliah bisa langsung bekerja di salah satu pabrik tersebut.

\section{d. Faktor Ilmu Pengetahuan Dan Teknologi.}

Meskipun perkembangan IPTEK semakin pesat, tetapi masyarakat Tugu tidak terlalu mengikuti perkembangan jaman. Hal ini juga dikarenakan faktor sarana dan prasarana penunjang di lingkungan yang tidak mendukung. Masyarakat Tugu sudah terbiasa terhadap hape tetapi untuk untuk penggunaan internet masih sedikit yang mampu mengunakannya. Warnet pun masih jarang ditemui di daerah ini

Sementara itu, untuk faktor internal lebih menggambarkan mengenai kondisi internal organisasi LDII di Kecamatan Tugu, yaitu :

\section{a. Pendanaan}

Sesuai dengan Anggaran Rumah Tangga (ART) Pasal 30, LDII mendapatkan dana dari sumbangan yang tidak mengikat, yang diperoleh dari bantuan atau sumbangan yang tidak mensyaratkan sesuatu kepada LDII. Sebagian besar dana sumbangan dikumpulkan dari warga LDII sendiri (swadaya). Selain dari warganya, LDII juga menerima sumbangan dalam berbagai bentuk dari pemerintah RI, swasta dan perorangan.

Uang yang terkumpul dikelola oleh bendahara yang dipergunakan untuk kepentingan organisasi seperti pembelian sarana dan prasarana serta 
untuk transportasi jika ada anggota yang hendak mengikuti kajian di luar cabang Kecamatan Tugu.

\section{b. Program Kegiatan LDII}

Program kegiatan LDII di Kecamatna Tugu secara umum mengacu pada pokok-pokok program yang dituangkan dalam Munas LDII. Sehingga kegiatan organisasi di kecamatan satu dengan yang lain saling terkait, bahkan ada program-program yang disusun dan dilaksanakan secara bersama dalam wilayah-wilayah kecamatan tertentu, seperti antara Kecamatan Tugu, Kecamatan Ngaliyan dan daerah Kalibanteng. Secara lebih lengkap program kegiatan LDII secara umum tercantum dalam tabel I berikut :

\section{Tabel 1}

\section{Program Kegiatan LDII Kecamatan Tugu Tahun 2013}

\begin{tabular}{|c|c|c|c|c|}
\hline \multirow{2}{*}{ No } & \multirow{2}{*}{ Program } & \multirow{2}{*}{ Frekuensi } & \multicolumn{2}{|c|}{ Kegiatan } \\
\hline & & & Kajian Al Quran & Kajian Hadits \\
\hline 1 & $\begin{array}{l}\text { Pengajian rutin } \\
\text { berkelompok } \\
\text { tingkat PAC }\end{array}$ & $\begin{array}{l}\text { Seminggu } 2-3 \\
\text { kali }\end{array}$ & $\begin{array}{l}\text { - Tafsir Jalalain } \\
\text { - Tafsir Jamal } \\
\text { - Tafsir Ibnu Katsier } \\
\text { - Tafsir Ibnu Abbas } \\
\text { - Tafsir Baidhowi } \\
\text { - Tafsir at Thobari } \\
\text { - Tafsir al Furqon dari } \\
\text { Depag }\end{array}$ & $\begin{array}{l}\text { - } \text { Kutubus Sittah } \\
\text { - Shohih Al Bukhori } \\
\text { (Fathul Baari dan } \\
\text { Irsyadus Saari) } \\
\text { - Shohih Muslim } \\
\text { (Kitab Syarah } \\
\text { Nabawi) } \\
\text { - Sunan Abu Daud } \\
\text { (Aunul Ma'bud) } \\
\text { - Sunan Nasa'i } \\
\text { (Syarah Jalaluddin } \\
\text { As Suyuthi, Syarah } \\
\text { Hasyiyatus Sindi) } \\
\text { - Sunan Tirmidzi } \\
\text { (Kitab Tuhfathul } \\
\text { Ahwadzi) } \\
\text { - Sunan Ibnu Majah } \\
\text { (Ta'liq Muhammad } \\
\text { Fuad Abdul Baaqi) } \\
\text { - Hadits Muwatho } \\
\text { (Kitab Aujazul Mu- } \\
\text { zalik Ila Muwatho) }\end{array}$ \\
\hline 2 & $\begin{array}{l}\text { Pengajian cabe } \\
\text { rawit }\end{array}$ & $\begin{array}{l}\text { Tiap hari } \\
\text { bakda magrib }\end{array}$ & $\begin{array}{l}\text { - Baca tulis Al Quran (h } \\
\text { - Hafalan doa-doa serta } \\
\text { - Rekreasi dan bermair }\end{array}$ & $\begin{array}{l}\text { uf pegon) } \\
\text { urat pendek }\end{array}$ \\
\hline 3 & $\begin{array}{l}\text { Pengajian } \\
\text { muda/mudi }\end{array}$ & $\begin{array}{l}\text { Malam } \\
\text { minggu }\end{array}$ & $\begin{array}{l}\text { - } \text { Tadarus } \\
\text { - Kajian Al Quran } \\
\text { - Kajian Al Hadits. } \\
\end{array}$ & \\
\hline
\end{tabular}




\begin{tabular}{|c|c|c|c|}
\hline \multirow{2}{*}{ No } & \multirow{2}{*}{ Program } & \multirow{2}{*}{ Frekuensi } & Kegiatan \\
\hline & & & Kajian Al Quran \\
\hline 4 & $\begin{array}{l}\text { Pengajian ibu- } \\
\text { ibu/ wanita }\end{array}$ & Sabtu sore & $\begin{array}{l}\text { - Membahas peran wanita sebagai ibu } \\
\text { - Membahas tentang kehamilan, haid, nifas, } \\
\text { bersuci (menjaga najis) } \\
\text { - Mendidik anak melayani dan mengelola } \\
\text { keluarga } \\
\text { - Ketrampilan perempuan yang berguna untuk } \\
\text { bekal hidup sehari-hari dan menunjang } \\
\text { penghasilan keluarga }\end{array}$ \\
\hline 5 & $\begin{array}{l}\text { Pengajian } \\
\text { umum }\end{array}$ & $\begin{array}{ll}\text { Satu } & \text { bulan } \\
\text { sekali } & \end{array}$ & $\begin{array}{l}\text { - Sebagai wadah silaturahmi antara jamaah } \\
\text { LDII untuk membina kerukunan dan } \\
\text { kekompakan jamaah. } \\
\text { - Merupakan forum gabungan antara beberapa } \\
\text { jamaah PAC dan PC LDII }\end{array}$ \\
\hline
\end{tabular}

\section{c. Metode Pengajaran dalam LDII}

Di dalam mengajarkan ilmu Al Quran dan Hadits, LDII tidak menggunakan sistem kelas seperti pada umumnya. Metode penyampaian guru membacakan Al Quran, mengartikannya kata perkata dan menafsirkannya dengan dasar penafsiran dari hadits yang berkaitan dan penjelasan beberapa ahli tafsir, misalnya Tafsir Ibn Katsier. Murid- murid mencatat arti kata perkata di dalam Al Quran dan juga penjelasan tafsirnya. Untuk Al Hadits pun menggunakan metode pengajaran yang sama, dimana guru dan murid samasama memegang hadits yang sama dan melakukan kajian. Hadits yang dipelajari adalah utamanya Hadits Kutubussitah (Bukhori, Muslim, Abu Dawus, Nasai, Tirmidzi, Ibn Majah) serta hadits lainnya seperti Malik al Muatho' dan Musnad Ahmad.

Selain itu, mereka juga mempelajari himpunan hadits sesuai dengan temanya, seperti kitab sholat yang berisi tata cara sholat sesuai ajaran Nabi Muhammad yang tertulis dalam beberapa sumber Hadits, kitab puasa (shoum), kitab manasik haji dan lain-lain. Dengan mempelajari hadits secara langsung dari kitab aslinya berarti secara langsung mengetahui suatu hadits apakah shohih atau lemah, sehingga terhindar dari rusaknya ilmu dan amal mereka. Metode pemaknaan perlafadz itulah yang membuat para anggota LDII banyak menguasai kata-kata Arab yang sangat berguna dalam kehidupan beragama. Misalnya mereka dapat mengerti apabila sedang membaca $\mathrm{Al}$ Quran tanpa harus mempelajari ilmu Bahasa Arab atau ilmu Alat (nahwu dan shorof) karena ulama LDII beranggapan bahwa pencerdasan ilmu Al Quran bukan hanya milik ulama tetapi untuk semua orang, karena memang Al Quran diturunkan untuk seluruh umat manusia bukan hanya ulama tertentu. 
Metode pengajaran dalam mengkaji Al Quran dan Hadits sama yaitu dibacakan kemudian diberi arti kata demi kata dan kemudian diterangkan arti serta maksudnya. Para anggota pengajian memberi arti pada setiap kata yang ditulis dibawah tulisan $\mathrm{Al}$ Quran ataupun hadits. Ada yang menulisnya artinya dengan huruf latin bagi mereka yang belum mahir dalam menulis arab dan bagi mereka yang mahir menulis arab, mereka memaknainya dengan menggunakan huruf pegon (pegon huruf arab digunakan untuk menulis bahasa Jawa).

Guru yang menyampaikan kepada muridnya baik bacaan, makna (diterjemahkan secara harfiyah), dan keterangan untuk bacaan Al Quran memakai ketentuan tajwid disebut dengan ilmu manqul.

\section{d. Kader atau Keanggotaan}

Pengkaderan di LDII berjalan dengan baik. Hal ini dilihat dari berjalannya kajian keagamaan yang berlangsung secara intensif. Kegiatan dapat berlangsung dengan baik. Ada kegiatan yang bersifat mingguan, bulanan dan tahunan dapat terealisir dengan baik. Hal ini hanya dapat dilakukan oleh anggota organisasi yang militan dan setia dalam memperjuangkan tujuan organisasi LDII.

Keanggotaan LDII bersifat tidak mengikat. Hal ini disampaikan oleh ketua PC Tugu yaitu Bapak Sarmin yang mengatakan bahwa anggota LDII mengalamai naik turun, dalam artian ada yang masuk menjadi anggota dan ada yang keluar dari keanggotaannnya. Anggota yang tidak aktif biasanya waktu kegiatan terbentur dengan jam kerja. Banyak anggota LDII yang bekerja sebagai pekerja pabrik yang waktu kerjanya diatur menggunakan shift yang terbagi menjadi shift pagi, siang dan malam.

\section{e. Komunikasi dengan Pihak Luar}

Komunikasi yang terjalin dengan pihak lain organisasi dapat terjalin dengan cukup baik. Demikian juga komunikasi dengan pihak pemerintah. Hal ini sering dilakukan oleh organisasi LDII bila mempunyai atau mengadakan kegiatan umum sering mengundang pihak pemerintahan. Contohnya ketika DPD LDII kota Semarang mengadakan pengajian umum, pengurus LDII kota Semarang mengundang Walikota Soemarmo (ketika masih menjadi walikota) atau yang mewakili untuk menghadiri kegiatan yang diadakan LDII.

Dalam musyawarah nasional pun panitia kegiatan mengundang Presiden Soesilo Bambang Yudoyono untuk berkenan hadir dan membuka jalannya kegiatan, selain mengundang pejabat pemerintah, pengurus pun mengundang ketua MUI, dan ketua organisasi agama lain. Hal ini 
menunjukkan adanya tali silaturahmi yang positif diantara LDII dengan organisasi keagamaan lainnya dan antara LDII dengan pihak pemerintah.

Akan tetapi yang masih menjadi persoalan adalah, meskipun LDII sudah mempunyai paradigma baru dengan menganggap orang di luar LDII tidak kafir atau najis, tetapi LDII masih menjaga keeklusifannya. Keeklusifannya ini dilihat dalam melakukan ritual ibadah sholat, anggota LDII masih enggan untuk melakukan sholat di masjid yang bukan LDII, dan masyarakat umum pun segan untuk melakukan ibadah sholat di masjid LDII. Jarak inilah yang menjadi hambatan dan komunikasi antarar sesama umat muslim.

\section{f. Posisi}

Organisasi LDII adalah organisasi dengan skala nasional di banyak propinsi yang bisa ditemui. Organisasi LDII mempunyai kantor pusat di Jakarta sedangkan pondok pesantren yang mempunyai basis jamaahnya bisa kita temui di berbagai daerah contohnya pondok pesantren "Nurul Hakim" desa Ngino, Plemahan, Kediri. PP Al Barokah desa Sruni, Sidoharjo, Ponpes "Gadingmangu" Perak. Ponpes "Nurul Azizah" desa Balongjeruk, Kunjang Kediri. Ponpes "Mulyo Abadi" desa Sendang Adi, Mlati Sleman, Ponpes "Baitul Makmur Wonosalam, Ponpes "Nurus Salam" Samarinda, dan yang paling besar adalah Pondok pesantren Walibarokah Burengan Banjaran Kediri yang berada di tengah kota Kediri, Jawa Timur.

Pondok Pesantren Walibarokah Burengan Banjaran Kediri adalah salah satu pondok pesantren besar di Indonesia. Ponpes ini memiliki fasilitas yang cukup lengkap yang dapat digunakan dalam proses pembelajaran para santri. Ponpes ini mampu menampung 2000 santri laki-laki dan perempuan serta 50 pengurus ponpes. Bangunan pondok berdiri diatas tanah seluas 3,4 hektar. Gedung ini dalam peresmiannya dilakukan oleh Menteri Siswono Yudho Husodo.

\section{Analisis}

\section{Konsistensi untuk Mencapai Tujuan serta Motto Organisasi LDII}

Keberadaan sebuah lembaga dalam menjalankan roda organisasi adalah untuk mewujudkan tujuan yang di inginkan seluruh anggota yang telah di susun dalam anggaran dasar dan anggaran rumah tangga. Organisasi akan kehilangan makna apabila arah tujuan yang dirumuskan tidak tercapai. Dalam mewujudkan tujuan organsasi, organisasi menyusun sebuah motto yang 
menjadi rujukan dalam menyusun strategi capaian kerja. Motto berisi nilainilai yang menjadi semangat dalam mewujudkan visi, misi dan tujuan.

Dalam mewujudkan arah yang hendak di capai, organisasi LDII senantiasa mengerahkan segala sumber daya yang dimiliki baik sumber daya material (sarana-prasarana) maupun sumber daya manusia. (lihat table II)

\section{Tabel 2}

Value Chain (Rantai Nilai) Primary activities

\begin{tabular}{|c|c|c|c|c|}
\hline \multirow{6}{*}{ 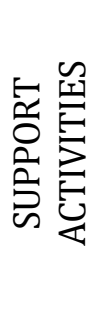 } & & Perencanaan & Dakwah & Pasca Dakwah \\
\hline & Organisasi & Ada & Baik & Baik \\
\hline & $\begin{array}{l}\text { Sarana dan } \\
\text { Prasarana }\end{array}$ & $\begin{array}{c}\text { Kurang } \\
\text { memadai }\end{array}$ & Kurang & $\begin{array}{c}\text { Kurang } \\
\text { maksimal }\end{array}$ \\
\hline & SDM & Ada & Baik & Baik \\
\hline & Keuangan & Ada & Cukup & Baik \\
\hline & SIM & Ada & Cukup & Baik \\
\hline
\end{tabular}

Melalui tabel diatas, organisasi LDII mempunyai perencanaan dan strategi yang baik. Hal ini juga ditunjang oleh sumber daya manusia yang baik, tetapi yang menjadi catatan adalah kurangnya sarana dan prasarana yang mendukung seperti tidak mempunyai masjid sendiri, lapangan olahraga sendiri.Dalam menjalankan ibadah sholat berjamaah, anggota LDII Kecamatan Tugu menginduk pada masjid LDII Puncaksari Kecamatan Ngaliyan. Demikian juga lapangan olahraga serta fasilitas lapangan olahraga lainnya masik menginduk kepada LDII cabang lainnya. Sedangkan untuk pendanaan hanya cukup memadai untuk operasional saja.

Dalam melakukan kajian rutin, LDII Kecamatan Tugumenggunakan sebagian rumah Bapak Sarmin sebagai Mushola inilah yang dipergunakan untuk kegiatan sehari-hari. Untuk melakukan sholat Jumat berjamaah atau lainnya, anggota LDII Kecamatan Tugumenggunakan masjid di Puncak Sari Kelurahan Tambak Aji kecamatan Ngaliyan. Meskipun berbeda kecamatan tetapi masjid ini dekat dengan Kecamatan Tugu. Lokasi masjid ini hanya di seberang selatan jalan raya, sedangkan pusat kegiatan LDII Kecamatan Tugu(mushola) hanya sekitar 300 meter kearah utara jalan raya. 


\section{Konsistensi terhadap Lingkungan Strategis}

\section{a. Kondisi internal}

LDII Kecamatan Tugu mempunyai kekuatan(strengness) yaitu:Pertama, Mempunyai jaringan organisasi yang luas dan berskala nasional bahkan internasional. Kedua, Mempunyai sumber daya manusia yang baik. Ketiga, Mempunyai pemahaman nilai keberagamaan yang tinggi.Keempat, Adanya AD/ART organisasi yang jelas dan terarah.

Adapun kelemahan (weakness) LDII di Kecamatan Tugu antara lain: Pertama,Sarana dan prasanara yang kurang memadai. Kedua, Pendanaan yang sekadarnya sehingga belum bisa mewujudkan sarana dan prasarana yaitu masjid, dan lapangan yang mencukupi.Ketiga, Jadwal kajian yang bersamaan dengan jam kerja sehingga terdapat beberapa anggota yang tidak bisa aktif mengikuti kajian sehingga keluar dari LDII.Keempat, Metode dakwah yang masih standar, kurang adanya inovasi seperti dakwah melaluimedia massa baik di media cetak maupun media elektronik

\section{b. Kondisi Eksternal}

Peluang dakwah bagi organisasi di Kecamatan Tugu yaitu: Pertama,Kondisi masyarakat Tugu yang mempunyai pemahaman keagamaan yang kurang. Hal ini ditandai dengan masih ditemukannya berbagai penyakit masyarakat di Kecamatan Tuguseperti judi, minum-minuman keras serta berzina, serta belum tegaknya sholat lima waktu, puasa dan zakat.Kedua, Kondisi masyarakat perkotaan yang dihinggapi budaya konsumtif, hedonis sehingga berkurangnya nilai-nilai keagamaan.Ketiga, Sebagian masyarakat Tugu terutama kalangan tua yang masih percaya adanya takhayul dan khurafat.

Ancaman dakwah bagi organisasi LDII antara lain: Pertama, LDII yang bersifat eksklusif, tidak mau membaur dengan masyarakat lain dalam hal ritual keagamaan. Meskipun sudah mempunyai paradigma baru tetapi belum seluruhnya paradigma ini masih terealisir. Paradigma ini masih dalam tataran konsep belum sampai ke tataran praktis di tingkat grass root (jamaah LDII di level bawah). Kedua, Masyarakat yang sudah mengganggap LDII sebagai Islam Jamaah, yang membuat masyarakat menjadi apatis dan mempunyai stereotif yang jelek terhadap LDII.Ketiga, Perkembangan dunia teknologi, informasi dan komunikasi yang harus diantisipasi dan dapat dimanfaatkan sebagai sarana dalam berdakwah 


\section{Kesimpulan dan Saran}

LDII mempunyai tujuan untuk meningkatkan kualitas peradaban, hidup, harkat dan martabat dalam kehidupan bermasyarakat, berbangsa dan bernegara serta turut dalam pembangunan manusia Indonesia seutuhnya, yang dilandasi oleh keimanan dan ketaqwaan kepada Tuhan yang Maha Esa guna terwujudnya masyarakat madani yang demokratis dan berkeadilan sosial berdasarkan Pancasila yang diridhoi oleh Allah SWT konsisten dalam mewujudkan tujuan organisasi tersebut.

Organisasi ini dalam menjalankan dakwah Islamnya disertai dengan rencana, program kerja serta evaluasi proses kegiatan. LDII dalam melakukan dakwahnya bersifat personal dengan cara mengajak umat muslim yang terdekat seperti saudara, tetangga untuk ikut dalam kegiatannya. LDII di Kecamatan Tugu masih mempunyai fasiltas yang terbatas karena hanya mempunyai musholla sedangkan fasilitas yang lainnya menggunakan fasilitas LDII cabang yang lainnya. LDII menggunakan strategi di bidang keagamaan, olah ragadan lainnya untuk mengembangkan dakwah Islam.

Saran-saran : Pertama, LDII agar bisa inklusif (terbuka) bersama dengan muslim lainnya melakuakan ritual keagamaan lainnya sehingga mengundang simpati masyarakat umum lainnya dalam malakukan dakwahnya.Kedua, Agar mampu dikembangkan sarana dan prasarana sehingga dakwah Islam mampu berjalan dengan maksimal.Ketiga, LDII mampu mengikuti perkembangan zaman. 


\section{DAFTAR PUSTAKA}

Amin, M. Masyhur, Dakwah Islam dan Pesan Moral, (Jakarta: al Amin Press, 1997).

Anas,Ahmad, Paradigm Dakwah Kontemporer, Aplikasi dan Praktisi Dakwah Sebagai Solusi Problematika Kekinian (Semarang: Pustaka Rizki Putra, 2006).

Basit, Abdul, Wacana Dakwah Kontemporer, (Purwokerto: Stain Purwokerto, Cet Pertama, 2006).

G. R Terry, Principles Of Management, (Georgetown: Richard D. Irwing Inc, sixth edition. 1972).

Hafiduddin, M.Sc, Didin. Dakwah Aktual, (Jakarta: Gema Insani Press. Cet 3, 1998).

Harits, M.Ag, Drs. A. Busyairi, Dakwah Kontekstual Sebuah Refleksi Pemikiran Islam Kontemporer, (Yogyakarta: Pustaka Pelajar, 2006).

http//www.ldii.or.id/in/ dan www.google.com.

Muchtarom, H. Zaini, Dasar-Dasar Manajemen Dakwah. (Yogyakarta: Al Amin Press, 1996).

Munir, M, dan Wahyu Ilaihi. Manajemen Dakwah. (Jakarta: Kencana Prenada Media Group. 2006).

Moeloeng, Lexy J., Metodologi Penelitian Kualitatif, (Bandung: CV Remaja karya, 1989).

Prasetya, Wirawan . Logika Dan Prosedur Penelitian, ( Jakarta: Sekolah Tinggi Ilmu Administrasi, cet kedua, 2000).

Pimay, L.c, M.A.g. Dr.H.Awaludin, Paradigma Dakwah Humanis, (Semarang: Rasail, 2005).

Ridho, Subkhan, Dinamika Keberagamaan Lembaga Dakwah Islam Indonesia Kalipancur, (Semarang: Balai Penelitian Pengembangan Agama Islam Semarang, 2010).

Suparta, M.A , Drs.H. Munzier dan H. Harjani Hefni, Lc, M.A, Metode Dakwah, (Jakarta: Kencana Prenada Media Group. Cet 3, 2009).

Sukir, Asmuni, Dasar-Dasar Strategi Dakwah Islam (Surabaya: Al Ikhlas, 1983). 
Shaleh, A. Rosyad, Manajemen Dakwah Islam, (Jakarta: Bulan Bintang. 1993).

Umar, Husein, Metode Penelitian Untuk Skripsi Dan Tesis Bisnis, (Jakarta:PT Rajagrafindo Persada, 2000). 